Владислав ЖОРНИЦЬКИЙ

\author{
Медичний кодекс України: \\ необхідність імплементації \\ міжнародно-правових стандартів \\ здійснення біомедичних \\ досліджень
}

\begin{abstract}
Стаття присвячена дослідженню питанню регулювання проведення біомедичних досліджень в українському законодавстві. Відзначаючи, що таке регулювання знаходиться в зародковому стані, підтримується ідея розробки і прийняття Медичного кодексу України на основі відповідних міжнародно-правових стандартів. Доведено, що в кодексі повинна знайти закріплення окрема глава про біомедичні дослідження та визначено основні підходи, на яких вона повинна базуватися (гарантування прав і свобод людини, пріоритет інтересів окремої людини над інтересами науки і суспільства, встановлення особливих гарантій уразливим особам, обмеження меж допустимого втручання, дотримання вимог наукової обгрунтованості).

Ключові слова: медичний кодекс, міжнародно-правові стандарти, кодифікація законодавства, біомедичні дослідження, етичне поводження, права людини.

The article is devoted to the study of the issue of regulation of biomedical research in the Ukrainian legislation. Noting that such regulation is in its infancy, the idea of development and adoption of the Medical Code of Ukraine on the basis of relevant international legal standards is supported. It is proved that the Code should contain a separate chapter on biomedical research and determine the main approaches on which it should be based (guaranteeing the rights and freedoms of the individual, the priority of the interests of the individual over the interests of science and society, the establishment of special guarantees for vulnerable persons, limiting the limits of acceptable interventions, compliance with scientific validity).

Keywords: medical code, international legal standards, codification of legislation, biomedical research, ethical behavior, human rights.
\end{abstract}

Постановка проблеми. Формування законодавчої бази в галузі медичної генетики в Україні, адекватної сучасному рівню розвитку цієї галузі знання, в даний момент тільки починається. Юридичне регулювання здійснюється загальним і спеціальним законодавством та підзаконними актами. Зокрема, багато питань, що стосуються дотримання прав пацієнтів, регламентуються положеннями Конституції України, Основами законодавства України про охорону здоров'я, положеннями Кримінального, Цивільного, Сімейного та деяких інших кодексів України та ін. Основні положення в галузі захисту прав людини визначені Конституцією України, в якій гарантуються: право на охорону здоров'я та медичну допомогу, добровільність участі в медичних, наукових та інших дослідах, недоторканність приватного життя, особисту і сімейну таємницю, недопущення збору, зберігання, використання та поширення інформації про приватне життя без згоди людини. Зважаючи на це, гостро піднімається питання кодифікації медичного законодавства України із визначенням змісту питання розроблення єдиного кодифікованого акту, який включав би норми, які врегулювали б суспільні відносини в сфері надання медичної допомоги та визначення безпосереднього змісту такого акту.

Аналіз останніх публікацій та досліджень. В українській науці існує більш-менш загальний консенсус необхідності прийняття Медичного кодексу України, який бачимо в роботах Р. О. Стефанчука [1], О. В. Любінця та I. Я. Сенюти [2], Р. А. Майданика [3] та інших дослідників. Разом з тим, в дослідженнях цих вчених досліджується загальне питання необхідності прийняття такого акту загалом, не торкаючись питання змістовного наповнення Медичного кодексу України. Щодо міжнародно-пра-

\footnotetext{
УДК 341(091):340.1

https://doi.org/10.36952/uail.2020.4.89-95

() В. Жорницький

\section{ЖОРНИЦЬКИЙ Владислав}

аспірант кафедри міжнародного права Інституту міжнародних відносин Київського національного університету імені Тараса Шевченка
} 
вових стандартів здійснення біомедичних досліджень, питань быоетики та мыжнародного права, то теоретичною основою даної статті стали роботи С. Абросімової, А. Боннікена, Є. Гладкової, Л. Глухарєвої, Т. Коваленко, Т. Короткого, І. Крусса, Д. Лур'є, М. Медведєвої, Б. Островської, А. Пломера, Г. Романовського, В. Третьякової, Е. Труханова, Н. Хендель.

Метою даної статі є визначення необхідності наявності окремої глави стосовно біомедичних досліджень в такому кодифікованому акті під умовною назвою «Медичний кодекс України» з урахуванням наявних відповідних міжнародно-правових стандартів.

Виклад основного матеріалу. Законодавство України в сфері поводження з генетичними даними знаходиться на зародковому рівні. Настільки зародковому, що законодавство не містить навіть визначення поняття «генетичні дані».

Разом з тим, термін «генетичні дані» зустрічається в законодавстві Украӥни. Стаття 7 Закону України «Про захист персональних даних» передбачає таке положення: «Забороняється обробка персональних даних про расове або етнічне походження, політичні, релігійні або світоглядні переконання, членство в політичних партіях та професійних спілках, засудження до кримінального покарання, а також даних, що стосуються здоров' я, статевого життя, біометричних або генетичних даних» [4]. Однак частина друга цієї статті містить довгий перелік виключень, коли положення частини першої статті не застосовується. Серед таких винятків $є$ положення: «необхідна в цілях охорони здоров'я, встановлення медичного діагнозу, для забезпечення піклування чи лікування або надання медичних послуг, функціонування електронної системи охорони здоров'я за умови, що такі дані обробляються медичним працівником або іншою особою закладу охорони здоров'я чи фізичною особою - підприємцем, яка одержала ліцензію на провадження господарської діяльності з медичної практики, та ії працівниками, на яких покладено обов' язки щодо забезпечення захисту персональних даних та на яких поширюється дія законодавства про лікарську таємницю, працівниками центрального органу виконавчої влади, що реалізує державну політику у сфері державних фінансових гарантій медичного обслуговування населення, на яких покладено обов'язки щодо забезпечення захисту персональних даних».

Незважаючи на такий довгий текст цього виключення, воно не дає відповідей на багато питань, наприклад, наскільки виправданою має бути така необхідність в цілях охорони здоров' я, хто приймає рішення про їі наявність або відсутність, щодо охорони чийого саме здоров'я повинна мати місце така необхідність. Однак відповіді на ці питання можуть знадобитися лише в тому випадку, якщо законодавство міститиме чітке визначення поняття «генетичні дані», адже в іншому випадку ці норми буде практично неможливо реалізувати. Це доводиться і практично повною відсутністю судової практики з питання захисту генетичних даних як персональних даних в Україні.

Прикладом належного законодавчого врегулювання одного з аспектів поводження з генетичними даними є Закон України «Про заборону репродуктивного клонування людини» (2004 p.) [5]. Цим законом введена заборона репродуктивного клонування людини в Україні, виходячи з принципів поваги до людини, визнання цінності особистості, необхідності захисту прав і свобод людини та враховуючи недостатню дослідженість біологічних та соціальних наслідків клонування людини. Разом 3 тим, дія цього закону не поширюється на клонування інших організмів.

Клонування людини визначається у зазначеному законі як створення людини, яка генетично ідентична іншій живій або померлій людині, шляхом перенесення у залишену без ядра жіночу статеву клітину ядра соматичної клітини людини. Ввезення на територію України та вивезення з території України клонованих ембріонів людини забороняється.

Особи, винні у порушенні цього Закону, несуть цивільно-правову, адміністративну або кримінальну відповідальність відповідно до законів України. Разом з тим, Кримінальний кодекс України належним чином не передбачає такої кримінально-правової відповідальності [6].

Україна підписала Конвенцію Ов'єдо 22.03.2002 р. та досі не ратифікувала ні їі, ні протоколи до неї. Як зазначає Б. В. Островська: «Тому питання ратифікації Конвенції Ов'єдо для України залишається відкритим. Воно є визначальним для міжнародно-правового підтвердження готовності до захисту прав та гідності людини, а також до відповідальності за їх порушення. Для цього на національному рівні потрібно ухвалити законодавство, яке б охоплювало ключові поняття, що стосуються біомедицини, для запобігання грубого порушення прав і гідності людини. Зокрема, мають бути врегульовані питання правового статусу ембріонів, яке б забезпечувало належний їх захист, питання використання стовбурових клітин, терапевтичного клонування, трансплантації (в тому числі, ксенотрансплантації), біомедичні та генетичні дослідження та багато інших. Загалом використання інноваційних технологій у медицині третього тисячоліття повинно здійснюватися виключно на користь людству, що має закріплюватися правом» [7, с. 99].

Як зазначає О. Р. Антонюк: «Однією з перешкод на шляху приєднання України до Конвенції була відсутність спеціального державного органа, який би розробляв і реалізував політику в галузі біое- 
тики. Нині цієі перешкоди вже не існує. Проте важливо розробити ефективний правовий механізм реалізації вимог Конвенції 1997 р., який забезпечуватиме наявність у законодавстві заходів щодо юридичної відповідальності. Зокрема, у проекті Кримінального кодексу України передбачалася кримінальна відповідальність за проведення досліджень 3 метою відтворення (реплікації) людини методом клонування. Однак цей пункт з Кодексу вилучили. Така норма видається необхідною, ії диспозиція має включати вказівку на незаконність подібних досліджень. Слід вжити певних заходів у зв'язку 3 можливістю проведення дослідів 3 клонування людини за межами національної юрисдикції (на території інших держав, у відкритому морі). До кримінального законодавства України варто ввести самостійну норму про кримінальну відповідальність за фінансування незаконних досліджень 3 клонування людини. Важливо, щоб критерій «законності» передбачав наявність певного порядку одержання дозволу на дослідження з використанням методики клонування людських клітин. Причому контроль не повинен бути виключно державним. Центральною ланкою такого контролю мають стати незалежні етичні комісії, утворювані в тих науково-дослідних установах, які проводять експерименти на людині і тваринах» [8].

Також необхідно систематизувати законодавство в межах системи Основ законодавства України про охорону здоров'я [9, с. 12]. Однак перед цим, необхідно обов'язково визначитися з бажаним рівнем деталізації правових приписів центрального законодавчого акту в сфері охорони здоров'я. «Основи» повинні представляти собою якийсь фундаментальний базис і закладати здебільшого норми-принципи, які потім отримають своє більш детальне висвітлення в інших законодавчих актах.

Зазначимо, що розширення сфери правового регулювання супроводжується іншою тенденцією поглибленням правового регулювання суспільних відносин, повнішим, конкретним і всебічним їх регламентуванням. На сучасному етапі поглиблення правового регулювання - це головний магістральний шлях розвитку сучасного законодавства.

У зв'язку з цим, більш прогресивним і обгрунтованим кроком, на думку автора, бачиться такий шлях як комплексна переробка існуючих правових актів та створення на їх основі нового документа кодексу. Саме розробка нового кодифікованого документа в сфері охорони здоров' я дозволить досягти поглиблення правового регулювання комплексних відносин, що виникають у галузі поводження з генетичними даними.

В даному випадку такий документ зможе на достатньому рівні деталізації регулювати суспільні відносини і буде, при правильному підході, на перших етапах потребувати тільки в формуванні системи підзаконних нормативних правових актів.

Доводи щодо створення Медичного кодексу України будуть виражені в наступних ключових моментах: обгрунтування необхідності його створення; обгрунтування вибору кодифікації, як форми систематизації правового масиву; визначення мети, завдань і структури створюваного нормативного правового акта.

Необхідність створення Медичного кодексу України в найзагальнішому вигляді пояснюється комплексом причин, в числі яких найбільш вагомими виступають наступні: послідовність законодавчого регулювання; наявність великої кількості дубльованих положень, колізійність, пробільність існуючого законодавства, необхідність його більш вузької спрямованості (спеціалізації), а також сприяння кількісному зменшенню нормативного матеріалу і підвищенню ефективності його використання [2].

Послідовність законодавчого процесу наочно простежується у сформованій системі вітчизняного законодавства. Деякі вчені стверджують, що кодифікація - найбільш перспективна відносно нормативно-правової бази України. Дійсно, прийняття кодексів - одна з найбільш популярних форм систематизації вітчизняного законодавства.

Потреби сталого розвитку законодавства про охорону здоров'я з усією гостротою висувають питання про його внутрішню структуризацію і систематизацію. На даний момент правові масиви формуються хаотично і часом нерідко одні й ті ж розпорядження дублюються в різних нормативних правових актах.

Такі питання, як права пацієнтів, лікарська таємниця, відповідальність, оскарження дій (бездіяльності) медичних працівників та інші є загальними поняттями для всієї системи охорони здоров'я, в зв'язку з чим, різні варіації їх регламентації можна виявити відразу в декількох нормативних правових актах. При цьому кожен акт може містити свої формулювання, може дублювати наявні, або мати бланкетні і відсильні норми, що змушують звертатися відразу до кількох правових актів.

Разом з тим, можна розділити обгрунтовану стурбованість правознавців щодо того, що створення багатьох кодексів не супроводжується проведенням глибокої кодифікації: немає програм кодифікації, в результаті за кожним кодексом «навздогін» готується пакет законів і підзаконних актів; залишаються без змін багато актів, що втрачають сенс в зв' язку з прийняттям кодексів; кодекси іноді бувають «тонкими» за обсягом регулювання через відсутність єдиних принципів і методологічних підходів. 
Природно, такий підхід до кодифікації законодавства не вирішує всіх потребуючих вирішення проблем, а, навпаки, створює додаткові складності.

Вибір кодексу в якості форми майбутнього законодавчого акту обумовлений, перш за все, достатністю деталізації правових приписів і необхідністю комплексної переробки несистематизованого правового матеріалу з метою створення стрункої гармонізованої системи норм у сфері поводження 3 генетичними даними.

В теорії права поряд з кодифікацією прийнято виділяти ще два основних види систематизації: інкорпорацію та консолідацію.

I. Я. Сенюта висловлює думку про те, що окремим видом систематизації слід вважати також облік нормативних правових актів, під яким пропонується розуміти діяльність зі збирання, зберігання та підтримання в контрольному стані нормативних правових, актів, а також створення пошукової системи, за допомогою якої здійснюється можливість оперативно знаходити потрібну правову інформацію [10, c. 242].

Інкорпорація - форма систематизації, при якій відбувається об'єднання різних нормативних правових актів у збірники, розташування їх у певному порядку. При цьому їх зміст залишається незмінним і кожен акт зберігає своє самостійне значення. Консолідація - така форма систематизації, при якій нормативні правові акти доопрацьовуються, доповнюються і об'єднуються в новий нормативний правовий акт. Результатом консолідації, як і при кодифікаційних роботах, є один нормативний акт, проте сам нормативний матеріал не переробляється, можлива лише редакторська правка, виняток окремих правових норм для усунення суперечності.

Окреслені вище причини створення єдиного нормативного правового акта в сфері охорони здоров'я свідчать про те, що жодна з зазначених форм систематизації не відповідатиме заявленим цілям, оскільки їх принциповою відмінністю є відсутність змістовної переробки систематизована масиву.

Принциповою вимогою до питання впорядкування правового матеріалу в сфері охорони здоров'я, у тому числі поводження з генетичними даними, є, таким чином, не просто облік, інкорпорація або консолідація, а серйозна переробка існуючих правових конструкцій, приведення їх у цілісну систему і усунення існуючих недоліків. Саме тому в якості прийнятного способу систематизації, здатного впоратися з покладеними завданнями, найбільш придатною є кодифікація. Ї̈̈ особливість полягає «в історично сформованій традиції конструювання такої моделі, коли в тканину правової матерії вплітаються нормативні узагальнення, правові засади регулювання, які кладуться потім в основу побудови того чи іншого блоку законодавства. Кодифікація дає міцний каркас, на якому тримається вся правова матерія тій чи іншій галузі або масиву законодавства».

В результаті кодифікації з'являються великі, внутрішньо систематизовані і узгоджені нормативні акти, ніж досягається найкраща якість правового регулювання суспільних відносин. Саме тому кодифікований акт дозволяє не просто впорядкувати законодавство, що регулює комплекс правовідносин і усунути наявні суперечності, породжувані відсутністю системного підходу, а й підняти на більш високий рівень утримання нормативного матеріалу.

Досягненню даної мети сприятиме рішення наступних взаємозалежних завдань:

1. Об'єднання в максимально можливій мірі в одному акті норм, що регулюють весь комплекс різноманітних відносин, що виникають у сфері охорони здоров'я.

2. Виклад нормативних приписів таким чином, щоб їх використання виключало двозначність тлумачення і не викликало труднощів при правозастосуванні. У той же час, важливо розуміти, що «зрозумілість» повинна виражатися не в доступності для будь-якого громадянина і супроводжуватися заміною таких категорій, як «презумпція згоди», «плацебо-дослідження», та інших на більш прості, а передбачати чітку логіку у викладі матеріалу , професійне використання юридичної техніки і т.д.

3. Закріплення єдиних «наскрізних» принципів правового регулювання відносин, що виникають у сфері поводження з генетичними даними. Зазначені принципи повинні увібрати в себе все вже вироблені вітчизняним законодавцем основні засади, а також грунтуватися на фундаментальних ідеях міжнародних правових актів.

4. Побудова чіткої системи взаємопов' язаних органів, посадових осіб і організацій, до компетенції яких входить діяльність 3 поводження з генетичними даними.

5. Встановлення функціонального механізму захисту прав пацієнтів/ випробовуваних при заподіянні шкоди з життя і здоров'ю у зв'язку з проведенням медичних втручань.

При цьому біомедичних досліджень за участю людини як досліджуваного повинна бути присвячена окрема глава цього документа.

На думку автора, дана глава повинна називатися «Біомедицина за участю людини як досліджуваного» і закріплювати основні положення, що регулюють дослідження, що проводяться за участю людини або ідентифікованого людського матеріалу. 
Зазначена глава повинна інтегрувати концептуальні норми проведення біомедичних досліджень, що містяться в Основах законодавства про охорону здоров'я громадян та інших документах, встановивши загальні положення для всіх досліджень і спеціальні норми для різних видів досліджень в залежності від характеру медичного втручання в людський організм (наприклад, при експериментальному хірургічному втручанні, випробуванні лікарських і хімічних засобів, генної інженерії, клонування і т.п.).

Залежно від структури створюваного нормативного правового акта в рамках загальних положень даної глави (або загальної частини, єдиної для всього документа) з метою формування однакового підходу до основних категорій, обов' язково необхідно закріпити і відобразити терміни та визначення, що стосуються проведення досліджень. Для повноцінного розкриття питань, пов'язаних з біомедичними дослідженнями вкрай важливо розкрити зміст таких понять: «біомедичне дослідження», «випробуваний», «інформована згода», «права людини при проведенні біомедичних досліджень», «генетичний матеріал», «генетичні дані».

Вже згадана глава поряд зі стандартною процедурою проведення біомедичних досліджень, повинна також закріпити окремі процедури можливості участі в дослідженнях спеціальних суб' єктів - вразливих груп населення (дітей у віці до 15 років, вагітних жінок, військовослужбовців, осіб, які відбувають покарання та інших) з метою забезпечення їх прав та свобод.

Недосконалість українського законодавства в сфері поводження з генетичними даними, викликане нігілізмом щодо норм біоетики, поточні українські законопроекти в цій галузі викликають необхідність звернення до зарубіжного досвіду по зазначеному колу питань.

Сьогодні немає, мабуть, жодної демократичної країни, де не визнавалася б важливість захисту прав людини в усіх сферах суспільного життя і в медицині зокрема. Права в цій сфері тісно пов' язані з питаннями етики і спираються на відомий всім перелік принципів: повага вільного і свідомого рішення пацієнта, право на вибір лікаря та згоду надати йому свободу визначення способу лікування в межах його компетентності, що надає сенс добровільною згодою, а також повагу життя і гідності людини, дотримання права на невтручання в приватне життя і на професійну таємницю.

Більш того, дуже складно бути коректним і етичним в цій сфері, так як кодекс проведення досліджень відбувається 3 консенсусу в даному конкретному суспільстві, пов'язаному 3 плюралізмом думок. Етичні стандарти зазвичай викладаються в загальних термінах. Це справедливо також для біоетики, оскільки, беручи до уваги різноманітність цінностей і концепцій людського життя, висвічується мінімальний набір правил, якого повинні дотримуватися всі члени суспільства.

Висновки і перспективи подальших розвідок. Нагальною є необхідність прийняття єдиного кодифікованого акту - Медичного кодексу України, - в якому повинна знайти закріплення окрема глава про біомедичні дослідження, яка повинна базуватися на таких основних положеннях: 1) свобода здійснення досліджень при дотриманні всіх законодавчих приписів, що регламентують захист людини, іï прав і свобод; 2) пріоритет інтересів окремої людини над інтересами науки і суспільства; 3) встановлення особливих гарантій і строго регламентованого порядку для участі в дослідженні осіб, які перебувають в безпорадному стані, або відносяться до уразливих груп населення; 4) проведення досліджень повинно обмежуватися сукупністю меж допустимого втручання в людський організм, вихід за які не може бути допустимим; 5) проведення досліджень повинно здійснюватися $з$ дотриманням вимог наукової обгрунтованості і доцільності, а також при наявності обов'язкового позитивного висновку спеціально уповноваженого органу - етичного комітету. Разом з тим, очевидно, що вироблення формулювання кожної статті запропонованої глави має відбуватися шляхом широкої наукової та публіцистичної дискусії юристів, лікарів, політиків, усіх зацікавлених осіб. Пропозиції такої дискусії, як і конкретні формулювання відповідних положень законодавства, повинні стати предметом подальших наукових розвідок у цій сферi.

1. Стефанчук Р. О. Кодифікація медичного законодавства в Україні: pro et contra. Публічне право. 2016. № 3. C. 27-34. URL: http://nbuv.gov.ua/UJRN/pp_2016_3_5.

2. Любінець О. В., Сенюта I. Я. Медичний кодекс як основа в реформуванні охорони здоров'я України. URL: http://www.umj.com.ua./arhiv/53/1683.asp.

3. Майданик Р. Законодавство України в сфері охорони здоров' я: система і систематизація. Медичне право. 2013. № 2. С. 63-74. URL: http:/ / nbuv.gov.ua/UJRN/medpr_2013_2_8.

4. Закон України «Про захист персональних даних» від 1 червня 2010 р. № 2297-VI $з$ подальшими змінами і доповненнями. URL: https:/ / zakon.rada.gov.ua/laws/show/2297-17\#Text. 
5. Закон України «Про заборону репродуктивного клонування людини» від 14.12.2004 № 2231IV. URL: https://zakon.rada.gov.ua/laws/show/2231-IV\#Text.

6. Триньова Я. О. Закон України «Про заборону репродуктивного клонування людини»: постатейний аналіз. Право і суспільство. 2013. № 6/2. C. 105-109. URL: http://pravoisuspilstvo.org.ua/ archive/2013/6-2_2013/25.pdf.

7. Островська Б. В. 20-річний ювілей Конвенції Ов'єдо: досягнення і перспективи. Наукові записки Iнституту законодавства Верховної Ради України. 2017. № 2. C. 99-104. URL: http://nbuv.gov.ua/UJRN/ Nzizvru_2017_2_18.

8. Антонюк О. Р. Етико-правові проблеми клонування людського організму. Медичне право України: правовий статус пацієнтів в Україні та його законодавче забезпечення (генезис, розвиток, проблеми і перспективи вдосконалення). Матеріали II Всеукраїнської науково-практичної конференції 17 -18.04.2008, м. Львів. URL: http://medicallaw.org.ua/uploads/media/02_007_01.pdf.

9. Ціборовський О. М., Істомін С. В., Сорока В. М. Шляхи систематизації законодавства україни у сфері охорони здоров'я. К., 2011. 72 с.

10. Сенюта I. Я. Концепція реформування законодавчого забезпечення охорони здоров'я України. Медичне право України: проблеми управління та фінансування охорони здоров'я : Матеріали III Всеукраїнської науково-практичної конференції з медичного права (II Міжнародної науково-практичної конференції з медичного права) «Медичне право України: проблеми управління та фінансування охорони здоров'я» (23-24 квітня 2009 р., м. львів) / упоряд. І. Я. Сенюта, Х. Я. Терешко. Львів, 2009. С. 240-248.

\section{Summary}

The legislation of Ukraine in the sphere of handling genetic data is at an embryonic level. It is so embryonic that the legislation does not even contain a definition of «genetic data».

It is the development of a new codified document in the sphere of health care that will enable to deepen the legal regulation of complex relations arising in the sphere of handling genetic data.

In this case such a document will be able to regulate social relations at a sufficient level of detail and will, with the right approach, at the first stages only require in formation of a system of subordinate normative legal acts.

The arguments on creation of Medical Code of Ukraine will be expressed in the following key points: substantiation of necessity of its creation; substantiation of choice of codification as a form of systematization of legal massif; determination of purposes, tasks and structure of created normative legal act.

The necessity of creation of Medical Code of Ukraine in the most general form is explained by a complex of reasons, among which the most significant are the following: consistency of legislative regulation; presence of a large number of duplicated provisions, collisionality, punctiliousness of the existing legislation, necessity of narrower focus (specialization), and promotion of quantitative reduction of normative material and increase of efficiency of its use.

Such issues as patients' rights, medical secrecy, responsibility, appealing the actions (inaction) of medical workers and others are common concepts for the entire healthcare system, so different variations of their regulation can be found in several normative legal acts at once. At the same time, each act may contain its own wording, may duplicate the existing ones, or have blanket and reference norms, which make it necessary to refer to several legal acts at once.

A fundamental requirement to the issue of streamlining the legal material in the field of healthcare, including the handling of genetic data, is therefore not simply taking into account, incorporation or consolidation, but a serious revision of existing legal structures, bringing them into a coherent system and eliminating existing shortcomings. That is why codification is the most appropriate way of systematization, capable of coping with the assigned tasks. Its peculiarity lies «in the historically established tradition of constructing such a model, when normative generalizations are woven into the fabric of the legal matter, the legal basis of regulation, are then put into the basis of building this or that block of legislation. Codification provides a solid framework on which the entire legal matter of a particular branch or array of legislation is based.

In this case, a separate chapter of this document should be devoted to biomedical research involving human subjects.

In the opinion of the author, this chapter should be entitled «Biomedical research involving human subjects» and should enshrine the main provisions governing research involving human subjects or identified human material.

This chapter should integrate conceptual norms for biomedical research contained in the Fundamentals of Health Care Legislation and other documents, establishing general provisions for all research and special 
norms for different types of research, depending on the nature of the medical intervention in the human body (for example, in experimental surgery, testing of drugs and chemicals, genetic engineering, cloning, etc.).

Depending on the structure of the normative legal act being created, within the general provisions of this chapter (or the general part of the whole document) in order to form a uniform approach to the main categories, it is necessary to fix and reflect the terms and definitions related to conducting research. For full disclosure of issues related to biomedical research, it is extremely important to disclose the content of such concepts: «biomedical research», «tested», «informed consent», «human rights in biomedical research», «genetic material», «genetic data».

This chapter along with the standard procedure for conducting biomedical research should also establish separate procedures for the possibility of participation in research of special subjects - vulnerable groups (children under 15, pregnant women, servicemen, convicts and others) in order to ensure their rights and freedoms.

There is an urgent need to adopt a single codified act - the Medical Code of Ukraine - which should contain a separate chapter on biomedical research, which should be based on the following main provisions 1) freedom to conduct research with observance of all legal provisions regulating protection of human beings, their rights and freedoms; 2) priority of interests of an individual over the interests of science and society; 3 ) establishment of special guarantees and strictly regulated procedure for participation in research of persons who are helpless or belong to vulnerable groups; 4) conducting research should be limited by a set of limits of allowed interference into human organism, exceeding which cannot be admissible in any way; 5) research should be conducted in compliance with the requirements of scientific validity and expediency, as well as in the presence of a mandatory positive opinion of a specially authorized body - ethics committee. 